\title{
RETROSPECTIVE AND MODERN ASPECTS OF THE DEVELOPMENT OF CHARITY
}

\author{
Natalia Arabadzhy'1, Iryna Korniienko²
}

\begin{abstract}
The article considers the retrospective and modern aspects of the development of charitable activity in the socio-economic sense, which is the assistance to other persons at the expense of own welfare or free time, and provided that this assistance does not harm other persons and is carried out within the law. Charity should benefit not only the immediate recipient of benefit but also society as a whole. The authors emphasize that the conducted study supports their hypothesis that under the conditions of globalization, society increasingly focuses on social issues that arise as a result of insufficient state resources and so charity becomes a factor in their successful resolution. The development of charity is a system of social, economic, and cultural factors. One of the stages of the development of charity was the creation of charitable foundations specializing in various fields: scientific, cultural, sporting, educational projects, assistance to needy families, help for orphanages, hospitals, fundraising for expensive treatment and other projects. In today's world, the attitude towards charity as a professional occupation has become widespread, becoming a "social norm." Charitable funds are a separate and important component of the charitable institution. The concept of "charity" came into the public consciousness as a humanistic call of a person to go to the needy, regardless of religious, national, racial, social affiliation or political or ideological beliefs. Retrospective analysis showed that forms of philanthropy in the advanced form existed already in ancient Rome and ancient Greece; in medieval Europe, they already acquired the status of state and social policy at the legislative level. In the Christian aspect of ancient Rus of the adoption of the Orthodox faith in 988, the foundations of charity are laid as socio-ethical norms of society. In the second half of the XVIII century, as a result of secularization, charitable societies, hospitals, almshouses, open by public organizations and private individuals arise, that is, there are social and state institutions of charity. And charitable funds, which are socio-economic professional activities, are beginning to develop. From ancient to modern times, charitable activity is carried out in the forms of patronage, sponsorship, volunteering, fundraising. Modern trends of charity include: increase of the non-profit sector and its internationalization; cooperation of charitable foundations, development of a social partnership with business, state bodies, and foreign funds; professionalization through the creation of network charity. In turn, charity abroad is characterized by growing professionalism, a variety of forms and programs of cooperation, the growth and expansion of the sphere itself and its importance for non-profit, in particular, socio-cultural activities. The undisputed leader in this area is the USA - the birthplace of modern sponsorship and fundraising. The authors conditionally distinguish three levels of charity. The typology and general characteristics of foreign charitable foundations, typical for the USA, European countries, and Ukraine, are presented. Features of creation and functioning of quasi-public funds are considered. On a global scale, the foreign activity of the US foundations is significant, and the expenditures exceed the official foreign aid budgets of many countries. However, their presence in Ukraine is relatively low. The volume of support is negligible compared to official support amounts: according to the OECD, the amount of grants actually received by Ukraine from other states and multilateral donors in 2011-2017 amounted to more than 5 billion USD while less than 0.1 billion USD came to Ukraine from US foundations. But this does not exclude the role of private donors in solving certain problems, in particular, in terms of supporting civil society, protecting the rights of vulnerable groups of the population, etc.
\end{abstract}

Key words: charity, evolution of charity, society, social policy, US charity, funds in Ukraine.

JEL Classification: G23, N31, N23, H49, H89, I38, 139

\footnotetext{
Corresponding author:

${ }^{1}$ International Humanitarian University, Ukraine.

E-mail: arabadjinb@gmail.com

${ }^{2}$ National University Odessa Academy of Law, Ukraine.

E-mail: manelo4ka@ukr.net
} 


\section{Introduction}

Economic, social, political, and cultural transformations of the last decades have created the prerequisites for the emergence in our country of the charity institutes characteristic of societies that have gone through the path of modernization. A large number of facts indicate the deployment of processes of their formation, despite the fact that they occur not very smoothly, not harmoniously, and as a rule contradictory. In such circumstances, it would be natural to conduct a wide range of studies of this process, both from the specific positions of various social sciences and in the context of interdisciplinary synthesis.

Let us consider retrospective and modern aspects of the development of charitable activity in the socioeconomic sense, which is the assistance to other persons at the expense of own welfare or free time, and provided that this assistance does not harm other persons and is carried out within the law. Charity should benefit not only the immediate recipient of benefit but also society as a whole.

Charity cannot be accompanied by a violation of human rights, on the contrary, it, first of all, is aimed at protecting the socio-economic rights of the individual and cannot be carried out in violation of the law (Benevolensky, Mersiyanova, 2010; Opilat, 2015).

In the context of globalization, we are increasingly focusing on social issues that arise because of the lack of state resources, and as a result, charity becomes a factor in their successful solution. The development of charity is a system of social, economic, and cultural factors. Education of the population should form the people's desire for environmental improvement. In these circumstances, when the effects of financial and economic reforms are felt, first of all, on socially vulnerable groups, charitable activity becomes of special significance in providing assistance to the poor.

One of the stages of development of charity was the creation of charitable foundations specializing in various spheres: support of scientific, cultural, sports, educational projects, assistance to the families of dead and wounded servicemen, assistance to orphanages, hospitals, provision of funds for treatment, etc. (Opilat, 2015).

Cardinal economic and social transformations haveled to radical changes in public life, in particular, in charity. Charitable activity and its role in society are influenced by numerous interacting tendencies of the modern world, such as the evolution of power; modernization and globalization of the economy; technological progress, which leads to the emergence of new ways of communication; the accumulation of experience in the implementation of charitable activities, which increases the ability to make reasoned decisions. In today's world, the attitude towards charity as a professional occupation has become widespread, become a "social norm." There are exchange and development of various ideas and technologies between organizations and countries. Charitable funds are a separate and important component of the charitable institution. Insufficient funding encourages the search for innovative models of additional funding for socio-cultural development. Multi-channel financing of culture, education, and science, which is based on a combination of budget and extrabudgetary sources, becomes a dominant position.

The purpose of the study is to determine the retrospective and contemporary aspects of socioeconomic development of the evolution of charity as a socially useful activity. Additional studies are also required for the formation of promising directions for expanding charity in countries with urgent needs through an extrapolation review of the development of charity in the world, an extended review of the current state of charity, the formation of charitable foundations, and an analytical review of US charitable activities in the world and Ukraine.

\section{The methodology of research}

The concept of "charity" came into the public consciousness as a humanistic call of a person to go to the needy, regardless of religious, national, racial, social affiliation or political or ideological beliefs. Recent studies in social sciences have shown that the moral principles of charity do not contradict the religious canons of any of the three world religions.

The charity was perceived by ancient societies in Egypt, China, and India as one of the human virtuous qualities. It was seen as disinterestedness and social payment to the needy. The charity was known to the ancient Jews. In the Talmud, charity is denoted by the word "tzedakah" (righteousness or justice). The followers of Judaism had various forms of manifestation of charity: the practice of debt relief, debt cancellation, charitable treasuries serving the redemption of captives, and providing a dowry to the poor newlyweds (Levandovsky, 1995). However, as an independent sphere of human being, charity appears in Ancient Greece. This was related to the fact that the Greek society, having accumulated a certain spiritual experience, among other areas of its existence begins to allocate a special sphere, where there are friendly feelings, moral relations and relationships. Thus, the concept of "charity" (philanthropy) is formed, which means love for people, a friendly attitude of one individual to another, and friendship. In the Roman church, the emphasis was placed on helping the sufferer on the very act of almsgiving. The purpose of charity was not to help the neighbour but the gifts in the name of God, who buys eternal bliss (Shtal, 1978).

In the historical context of social charitable events of the period of antiquity, in particular in the Odyssey of the ancient Greek poet Homer, the original form of charity - alms (Shtal, 1978). Charity in that period was 
based on polis ideology, a kind of socially useful activity: alms were made mainly for the sake of social and cultural goals (Govorenkova, 2004). As Shtal I. V. (1978) noted, the absorption of the individual by the state in ancient Greece was, as is known, even in the social nature of consumption, so, of course, the issue of care for the poor was surely a state issue. On the other hand, the poorest part of the population was slaves, whose provision was the sole responsibility of their owners.

In Europe, the French king Charles the Great began the guardianship over the poor in 779 , and he imposed a tax in favour of the poor on all vassals, bishops and abbots, obliging them to maintain a certain number of the poor. At the same time, it was forbidden to ask alms and give it. The indicated policy did not reduce the needy, on the contrary, their number increased (Levandovsky, 1995). There was a need for more active state intervention in the process of combating poverty. At this stage, there were legislative approaches to the regulation of poverty and begging in European countries. During the XVI century, "Poor Relief Acts" were adopted in England, France, and Germany. The famous law of Queen Elizabeth (1601) even empowered local parishes to collect a special tax for the poor (poor rate). Legislative acts of European monarchies, adopted during the Middle Ages, became, in fact, the first laws on public welfare. Civil society assumes the responsibilities of rendering assistance to all needy; the ideology of Christian mercy is replaced by the ideas of social engineering. State forms of relief are emerging, as well as attempts to create specialized social institutions (almshouses, shelters). The most widespread philanthropic activity takes place in the second half of the XIX century, especially in England, France, and Germany, where it relied on significant support of state power (Kotilko, 2011).

Historians also found the need to provide assistance to "poor and deserted" in the Treaty of Prince Oleg with the Greeks in 911 (Govorenkova, 2004). Since the adoption of the Orthodox faith in Russia in 988, the foundations of charity - the moral duty of the rich to help the poor are laid (Kotilko, 2011). Helping the needy becomes the foundation of the ideology of the Christian religion. This is also stated in the Statute of Volodymyr the Great of 996, where a special part of society, which was separated from the Christian flock and was named as church or almshouse people, was handed over to the church. This part of society in all their church and nonchurch affairs was in charge of ecclesiastical authority. It consisted of the following: secular and regular clergy with their families; laity who served the church, or those who solved various worldly needs of people; homeless and poor people (Stupak, 2009).

In a further development, as emphasized by historians D. I. Bahalii and L. I. Lanchukovska, brotherhoods that created and held schools and hospitals occupied a significant place in the charitable church activity in Ukraine. In Sloboda Ukraine, the first charitable affairs of the brotherhoods date back to 1678 (Lanchukovska, 1997).
D.I. Popov notes that in the second half of the XVIII century, as a result of secularization (the removal of church lands from the monasteries), the closure of monasteries, there was a sharp decline of church charity. At the same time, charitable societies, hospitals, almshouses opened by public organizations (zemstvos, cities) and private individuals, arise massively. Eparchial guardianships were created for poor representatives of spiritual ranks who had the right to raise funds in their parishes (Popov, 1907).

At the end of the XVIII century, charitable establishments for numerous soldiers' children are started to be formed; the Technicum for the Deaf is established in Pavlovsk; in 1811, Obstetric Institute with maternity hospital for poor women, and also houses for soldiers' widows are established. In 1802, the first almshouse was opened as a house for the poor in Gatchina, the custody house for the blind (Charitable Russia, 1901). Studying the formation of charitable orphanages, P. Ye. Horbunov stated that this idea has emerged in society in the second half of the XIX century, the purpose of these establishments is as follows: come to the aid of families suffering from poverty, give a moral orientation to children who live in poverty from the cradle, to deprive cities of child beggars. For this purpose, the Orphanages Committee was established, which activity was aimed at social security of orphans (Charitable Russia, 1901).

Studying charity as an attribute of civil society, scholars M. F. Dmytriienko and O. V. Yas draw attention to the Ukrainian traditions of charity. The Kyivan princes, the Cossack hetmans and the colonels carried out charitable acts and showed mercy, built churches at their own expense, and contribute huge funds to monasteries. D. I. Yavornytskyi wrote that hetman Petro Konashevych-Sahaidachny was famous for his charity, he was worried about people's education, the placement of public schools, and he left for the poor hospitals and cash payments for their living until the end of their days (Yavornytskyi, 1991).

Investigating the historical traditions of the world about guardianship of the poor, P. I. Heorhiievskyi noted that gradually the matter of assistance to the neighbour is formalized, degenerated, it is no longer a help considered to be a charitable deed, but a sacrifice, a donation of the rich to the poor as depriving himself of some share of material wealth. Such an approach permeates charity in Europe in the Middle Ages. So, since 1547 in France, the focus is again on the need to care for the poor, it becomes a state matter, and taxes in favour of the poor appear (Vaillant, 1906). In 1597, the Charitable Uses Act was presented in England, which stated that charity funds could be used to help elderly, helpless, and poor people, to support sick and crippled soldiers and seamen, etc. (Vaillant, 1906).

In other countries of the world, the beginning of the $\mathrm{XX}$ century was marked by the emergence of private 
charitable foundations. The first private charities were established in the USA. Thus, the Carnegie Corporation of New York was founded in 1911, the Rockefeller Foundation in 1913, and others. Thus, charity becomes a part of entrepreneurship, the owners of large companies have sought to avoid excessive taxes and hide their property from income tax. As we see, a charity in the world is gradually becoming the prerogative of large companies, which are ready to give up a small part of the funds in order to protect their property. At the heart of such charity are the purely economic interests of individuals and legal entities. The French researcher É. Vaillant, analysing the peculiarities of charity at the beginning of the XX century, wrote that public trusteeship is becoming a new form of charity. The state of the ruling bourgeoisie, taxing the people, helped the poor not so much in order to reduce their poverty, so much so to soothe their anger against oppressors (Vaillant, 1906).

Since 1917, social policy in the field of charity in the territory of the Russian Empire is fundamentally changing. With the formation of the Soviet Union, the existing in the Russian Empire charitable organizations are started to be liquidated. Guardianship of those who suffer becomes solely a function of the state (Private foundations, 2010-2017). The phenomenon of publicprivate philanthropy in the Soviet Union loses its significance.

The emergence of an independent state of Ukraine once again set the need for society to return to the best Christian traditions, including the need for the revival of charity. Analysing the phenomenon of charity and its manifestation in the life of society, Ye. A. Shelekhov emphasizes that charity is an important auxiliary mechanism that partly eliminates the shortcomings of the social policy of the state (Kotilko, 2011). In today's conditions, the question arises about the social responsibility of business representatives for their activities and their awareness of the need for charitable activities for the benefit of society.

Unfavourable tendencies in the Ukrainian economy cause the actualization of the self-organization of society and its moral aspect. The role of the latter was emphasized by Scottish economist A. Smith, who argued that the basis of obtaining wealth is selfish interest the "invisible hand of the market", forcing a person to interact with other people, studying own interests while also contributing to the general benefit: "Give me what I need and you will get what you need..." (Menger, 1870) The issue of self-organization of society through the achievement of personal goals was studied by many representatives of the Austrian School of Economics. Representatives of the Austrian school were convinced that complex social phenomena can be explained as a consequence of the actions of specific individuals who in their economic activities follow certain economic laws.
One of the founders of the Austrian School, Ludwig von Mises, acknowledged that often institutes arise as an unintended result of actions aimed at achieving other goals, but for the study of institutions and the evaluation of their effectiveness, it is necessary to use the mind in social analysis (Mises, Ludwig von, 1949). Emphasizing that human activity always involves the use of means to achieve a specific goal, Mises wondered whether the planned state intervention was the appropriate means to achieve the desired goal.

Menger (Menger, 1870), Mises (Mises, Ludwig von, 1949), and Rothbard (Rothbard, Murray N., 1998) all of them were united in the fact that the main problem of economic science is not the description of the market, which it would be in a situation of equilibrium - this is impossible - but the study of the interaction of forces that make up the market process. An idea that unites all areas of the social economy is to analyse human activity, which allows formulating the basic economic principles of charity: charity is the deprivation of a human from the need for charity. In other words, sponsorship, donations, and assistance should be aimed at ensuring that the person who receives it no longer needs it. However, in the works of many economists, issues of charity as a specific kind of redistribution of economic benefits, principles of charitable organizations, prospects for the development of economic foundations of charitable activities in Ukraine are not sufficiently explored.

\section{Results and discussion}

The social policy of the state, ideally, is the derivative of institutionalizing the cooperation of citizens in the realization of their personal social and charitable aspirations and social state and non-state institutions. The wider the field of consensus, the less tangible the confrontational component of social policy, the more so on other equal terms, this policy is stable, strong, and predictable. But the consensus in this case is the coincidence of personal philanthropic aspirations of citizens. Why do the actions of the state are needed for their implementation? The answer is given by economic theory, and in a simplified presentation, it is as follows. If a citizen is not sure that the goal for which he is ready to spend his energies and money will be supported by the forces and means of many fellow citizens, for him it is often irrational to do individual actions. For example, a small donation will not change anything in the state of health. However, a citizen may willingly vote to withdraw this amount from him in the form of a tax if he is sure that, firstly, he the actions approved by him will be financed, and secondly, due to taxation, funds of other persons will be attracted too (Opilat, 2015).

There are several conditional levels of charitable activity. The first one is that in which charity is carried out on a purely individual basis without the need for any developed institutional form. At the second level, 
charity is represented by the activities of formal and informal structures of civil society, such as charitable foundations. Institutionalization within such structures allows, on the one hand, uniting efforts and, on the other hand, efficiently and in a controlled manner spending the donations of great benefactors (Paweł Dziekański, 2017). This, of course, helps to achieve more complex and meaningful goals than at the first level. But for the second level, there are boundaries, and where philanthropic goals go beyond them, a further complication of charitable institutions is required, based on their integration into the institutional framework of the state. Opportunities to achieve social goals are sharply increasing. For this reason, the number of resources involved and used at the third level is much higher than in the second, not to mention the first one.

However, the transition from level to level is, in essence, an increase in the institutional capacity of actions, but not a change in their nature. Nature, however, is most directly manifested where charity cannot be concealed with the envelope of state policy (the picture is obscured if the state is accustomed to perceive as something separate from citizens). Analysis and forecast of mature social policy are impossible beyond the context of charitable activities.

The task of developing self-regulation in the field of charity and volunteering in Ukraine is also very important. The transition from the existing system of monitoring charitable organizations is necessary, which is carried out almost exclusively by state authorities, to the system of state and public control, in which, along with state bodies, associations and unions of charitable organizations take part (Martynyuk, 2015). Formation and development of the system of self-regulation, mixed public-public control allows providing a reliable multi-faceted information system aimed at disclosing the activities of charitable organizations, needed both for donors and potential beneficiaries, and for the state, willing to verify the justification for granting possible benefits for charitable activities (Benevolensky, Mersiyanova, 2010).

\section{Typology and general characteristics of foreign charitable foundations.}

Foreign private funds can be categorized with a certain share of conventionality according to the sources of financing and activities.

So, American funds for analysis purposes are divided into five main groups, namely (Raik, Kristi, 2006):

- independent funds - charitable organizations, based on a financial endowment, the founders of which are private individuals (such as the Charles Stewart Mott Foundation) or families (e.g. Bill \& Melinda Gates Foundation);

- funds funded by companies. By their "nature" they are practically similar to independent charity organizations; however, unlike them, they are created by companies, not by private individuals;
- operating funds - organizations that manage projects funded by the third party, but in some cases, they may also finance certain projects at their own expense;

- community funds - are, in fact, instruments for mobilizing financial and other resources from different sources to meet local needs;

- public funds are organizations that collect public funds to finance their own grant programs. Most community funds are also public funds.

In the European space, in our opinion, the structure of the non-state private funds' sector has the following classification (Toepler Stefan, 2016):

- private funds - organizations based on a financial endowment created by individuals or families (similar to US independent funds);

- operating funds - funds created for the management of certain institutions or projects (these funds are similar to the corresponding American organizations); - funds financed by companies - independent legal entities and correspond to similar types of funds in the USA. These structures are created mainly by large companies (corporations);

- funds owned by companies - are created to manage companies, in particular, to prevent fight for control and among successors. For example, the Robert Bosch Stiftung GmbH owns Bosch;

- funds with public administration - organizations with a private endowment that is under the state administration;

- funds with state financing - government-created organizations, the funds for the endowment of which are also provided by the state.

Quasi-public funds

It should be noted that for some countries in the West, the practice of distributing a part of international assistance through funds, which are formally independent and non-governmental, has become traditional. At the same time, such funds can be called quasi-public, because to some extent their activities are under the supervision of the government. For example, support for the development of democracy is under the influence of a donor country's political model (Toepler Stefan, 2016).

The activity of quasi-public funds corresponds to the foreign policy of the state. Their activities are primarily aimed at supporting non-governmental organizations and civil society, where quasi-public funds show better efficiency. Thus, quasi-public funds are legally independent organizations, which are mainly statefunded and to some extent dependent on the state's policy (in particular, their activity is one way or another in line with the state policy in the relevant areas and under its particular supervision).

The use of funds has a number of advantages over official assistance: greater flexibility and innovation; faster reaction to change the working environment; less dependence on bureaucratic processes; lower reporting 
requirements; the work of "independent" funds is less associated with interference in the internal affairs of countries.

A classic example of quasi-public funds is the German political foundations, which are also called "party" (viva). They began their active foreign activity back in the 1960s in Latin America, and later the German model of the international work of party funds was tested in post-authoritarian countries such as Spain and Portugal in the 1970s. The funds provided support to parties or individuals in other countries, which over time allowed the construction of appropriate partner networks around the main institutionalized political trends in Europe (Building Foundations, 05.06.2010).

German political foundations have become a model for imitation in other states. And now, such political funds are already established and operate in a number of Western European countries. In particular, in the 1970s, party funds were created in Austria, and in the 1990s the German model was introduced by the Netherlands (the strategic goal - to support the process of global democratization) and Sweden (the strategic goal to support the development of democracy in the postSoviet space). In 1992, the Westminster Foundation for Democracy began its activities in Great Britain. The largest parties in Spain in the 2000s also created the respective party funds to support ideologically close political parties abroad. Today, similar organizations are developing in the countries of Central and Eastern Europe, which had previously been the object of supporting the relevant western funds (Building Foundations, 2010).

Today in Ukraine, there is no special law that would apply to the activities of various types of funds. In 1997, the Law of Ukraine "On Charity and Charitable Organizations" was adopted, replaced by the Law of Ukraine "On Charitable Activity and Charitable Organizations" in 2012 (Law of Ukraine, 2013). The first charitable foundations operated in the format of associations.

According to the current legislation, a charitable organization is a legal entity of private law whose founding documents define charitable activities in one or several areas determined by this Law as the main purpose of its activity. The list of charitable areas includes (Law of Ukraine, Art. 3, 2013):

1) education;

2) healthcare;

3) ecology, environmental and animal protection;

4) prevention of natural and technogenic disasters and elimination of their consequences, assistance to victims of disasters, armed conflicts and accidents, as well as refugees and persons in difficult living conditions;

5) guardianship and trusteeship, legal representation and legal assistance;

6) social protection, social security, social services and poverty reduction;

7) culture and art, cultural heritage protection;
8) science and research;

9) sports and physical culture;

10) human and civil rights and fundamental freedoms;

11) development of territorial communities;

12) development of international cooperation of Ukraine;

13) stimulation of economic growth and development of the economy of Ukraine and its separate regions and an increase of Ukraine's competitiveness;

14) assistance in the implementation of state, regional, local, and international programs aimed at improving the socio-economic situation in Ukraine;

15) assistance in defence capability and mobilization readiness of the country, civil protection in emergency situations of peace and war.

According to the State Fiscal Service, in early 2016, more than 15 thousand charitable foundations and organizations were registered in Ukraine. There is a lack of information on the activities of a number of entities over the lack of their financial reporting. However, in 2015, 9500 entities reported spending on charitable programs worth almost 9.4 billion UAH. Almost one-third of all charitable spending fell to top 5 largest funds. At the same time, the largest 100 funds spent in the amount of 6 billion UAH (two-thirds of the amount indicated). Thus, the rest of the charitable foundations and organizations accounted for only 3 billion UAH or somewhat more than 300 thousand UAH on average per entity (GulevskayaChernysh Anna, Yaroshenko Lesya, 2016).

In 2005, the first professional association of Ukrainian charitable foundations and associations was created - Ukrainian Philanthropists Forum (UPF). The founders of the UPF were the Initiative Centre to Support Social Action "Ednannia" and "Renaissance" International Foundation. This was done with the participation of international donors: the Charles Stewart Mott Foundation, the Institute for Sustainable Communities/UCAN, and the PolishAmerican-Ukrainian Cooperation Initiatives (Vinnikov Alexander, 2008). Today, the association has about 30 full members and about 10 associated ones. The UPF has been conducting a National Philanthropic Rating for several years. In 2016, only 89 charitable funds and organizations that publicized their tax reporting took part in the ranking. They accounted for 1.8 billion UAH or more than a quarter of the total spending on charity in 2016 (Gulevskaya-Chershin, 2017).

These data indicate that Ukraine is developing a private philanthropic sector; however, an assessment of the real scale, directions, and results of initiatives and projects supported by Ukrainian philanthropists needs special research.

\section{Activities of American charitable foundations in Ukraine.}

The vast majority of American charity organizations are relatively small institutions focusing on solving predominantly local problems. However, the US 
nonprofit sector is large in size - as of September 30, 2017, the US Internal Revenue Service (IRS) register had 1.3 million charitable organizations (IRS Data Book, 2017). In the fiscal year of 2015, 16209 thousand US charitable organizations that filed tax returns had assets worth 3.7 trillion USD and total revenues 2 trillion USD (Lanchukovska, 1997; Menger, 1870). It is worth noting that most of the income and expenditure of charitable organizations in the USA - the results of the work of non-profit health and educational institutions. A considerable part of the education and health sector in the USA - non-profit organizations.

Donor funding and grants were smaller. Funds and goods attracted by donors amounted to 204 billion USD, and issued grants - 172 billion USD; from a total of 172 billion USD for grants in 2015 fiscal year, American organisations received 89.6 billion USD, private individuals from the USA received 57.7 billion USD, and individuals and organizations outside the USA received 25.2 billion USD (Organizations Balance USA, 2015). Consequently, a small share of US charitable organizations' resources is directed abroad: less than $15 \%$ of total grants and slightly more than $1 \%$ of total revenues. However, 25 billion USD is an amount that exceeds the combined annual budget of foreign aid from Germany and Britain (the largest bilateral official donors after the USD).

In exchange for tax exemptions, US charitable organizations are required to submit detailed information on their work to the US Internal Revenue Service (Form 990). These reports are publicly accessible with some exceptions. In particular, information about recipients of grants outside the USA is a part of the reporting but is not made public as regards to public charities (Foundation Directory Online). Information on funding and geographic region of the recipient is published.

Activities of private foundations are regulated more thoroughly (for example, they must use at least 5\% of their assets for charitable purposes) and they submit more detailed accounts.

In the USA, there are a number of organizations collecting information about the performance of charitable organizations. In particular, the Foundation Centre maintains a database of information on the overwhelming majority of the grants provided by the US private foundations (Foundation Directory Online). Information is collected from public accounts and grant information provided by some foundations directly to the Foundation Centre. The database contains data on grants provided in 2003-2015 and a more limited set of data for 2016, 2017, and 2018. For example, as of the end of August 2018, the database contains information about 2.3 million grants given in 2015 by 74161 donors to 333627 recipients worth 76.1 billion USD. Of these, 4572 donors provided grants to 39875 recipients for a total of 16.8 billion USD to work outside the USA.
It should be noted that a significant part of grants in support of other countries is provided for American organizations -6.7 billion USD out of 16.8 billion USD. The main areas of support were healthcare and education (Burakovsky, Angel, Kravchuk, Yuhimenko, 2018).

Ingeneral,US charitable foundations paid relatively little attention to Ukraine. As at the beginning of August 2018, the Foundation Centre database contained information about 1521 grants worth a total of 103.5 million USD or $0.1 \%$ of the total amount of external grants from US private foundations. Is it a lot or a little? Given that Ukraine accounts for $0.6 \%$ of the world's population and $0.3 \%$ of world GDP, it is quite small.

It should be noted that the classification of grants by the geography of activities is conducted by the Foundation Centre on an algorithmic basis and, therefore, is not always accurate. In addition, a number of grants were issued to work in several countries. In order to estimate the volumes of funds directly received by Ukraine, we, first of all, excluded from the list those grants for which the geography of the work was determined incorrectly (Shtal, 1978; Stupak, 2009). Secondly, we estimated the share of Ukraine in grants that were implemented in several countries at the same time. According to our calculations, Ukraine in 2011-2018 received approximately 72.8 million USD from the CF of the USA (Gulevskaya-Chershin, 2017).

Within this article, we will analyse the support provided to Ukraine by American foundations since 2011. The largest private US donors in Ukraine during this period were the National Endowment for Democracy, the Foundation to Promote Open Society, the Charles Stewart Mott Foundation, and the CocaCola Foundation.

Table 1

The main donors of Ukraine according to the Foundation Centre database in 2011-2018

\begin{tabular}{|l|c|}
\hline \multicolumn{1}{|c|}{ The name of the charity organization } & $\begin{array}{c}\text { Amount, } \\
\text { million USD }\end{array}$ \\
\hline National Endowment for Democracy & 25,0 \\
\hline Foundation to Promote Open Society & 11,1 \\
\hline Charles Stewart Mott Foundation & 8,0 \\
\hline Coca-Cola Foundation & 4,1 \\
\hline Nationale Postcode Loterij (the Netherlands) & 3,0 \\
\hline Sigrid Rausing Trust (Great Britain) & 1,1 \\
\hline Ukrainian Women's Fund (Ukraine) & 1,1 \\
\hline Other & 17,6 \\
\hline
\end{tabular}

Source: Compiled by the authors based on Burakovsky I., Angel Ye., Kravchuk V., Yuhimenko S. (2018)

The volumes of annual support for Ukraine from US charitable foundations ranged from 9 to 14 million USD. The peak of revenues fell to 2014 - at the height of the Revolution of Dignity, and the least value was observed in 2012. Annually several hundreds of grants ranging from 10 to several million USD were issued. The largest 
grant was a grant from the Netherlands lottery Nationale Postcode Loterij UNICEF for the amount of 3 million USD in support of homeless teenagers in Ukraine and Moldova (Gulevskaya-Chershin, 2017).

There are also a number of "specialized" donors in Ukraine that provide funding to organizations in a relatively narrow area, as well as donors that support only individual projects. For example, Tides Foundation has funded a number of AIDS treatment projects, inclusive education, and the protection of the rights of persons with disabilities. The Elton John AIDS Foundation supported the work on AIDS prevention among vulnerable groups of the population within several projects. Omidyar Network Fund supported the creation of the New Citizen platform and the work of the Public Television. Mama Cash has supported several LGBT organizations and women's rights organizations.

The Disability Rights Fund supported projects for people with disabilities such as inclusive education, adoption of regional strategies, access to justice, accessibility of the transport system, and others.

The Global Fund for Children supported rehabilitation and psychological support for children with disabilities, early intervention for children, and adaptation of orphanages' graduates. The total funding from the aforementioned donors amounted to 4.3 million USD (Burakovsky, Angel, Kravchuk, Yuhimenko, 2018).

A fair amount of money was drawn from US foundations in support of religious communities in Ukraine, support for religious education in Ukraine, support for humanitarian initiatives, in particular, for the Jewish community of Ukraine. The Tikva Jewish Community ( 3 million USD) and the Ukrainian Catholic University (2.3 million USD) were the most successful in attracting funding from American private donors and jointly attracted almost two hundred grants since 2011 .

\section{Conclusions}

In dictionary literature, the concept of "welfare" is interpreted as all useful, serving human happiness, wellbeing - this is life in abundance, calm and happy state; charity - a willingness to do good, help the poor. In scientific literature, the charity was seen as a system of measures aimed at the organization of assistance to the poor in the presence of appropriate social and economic relations.

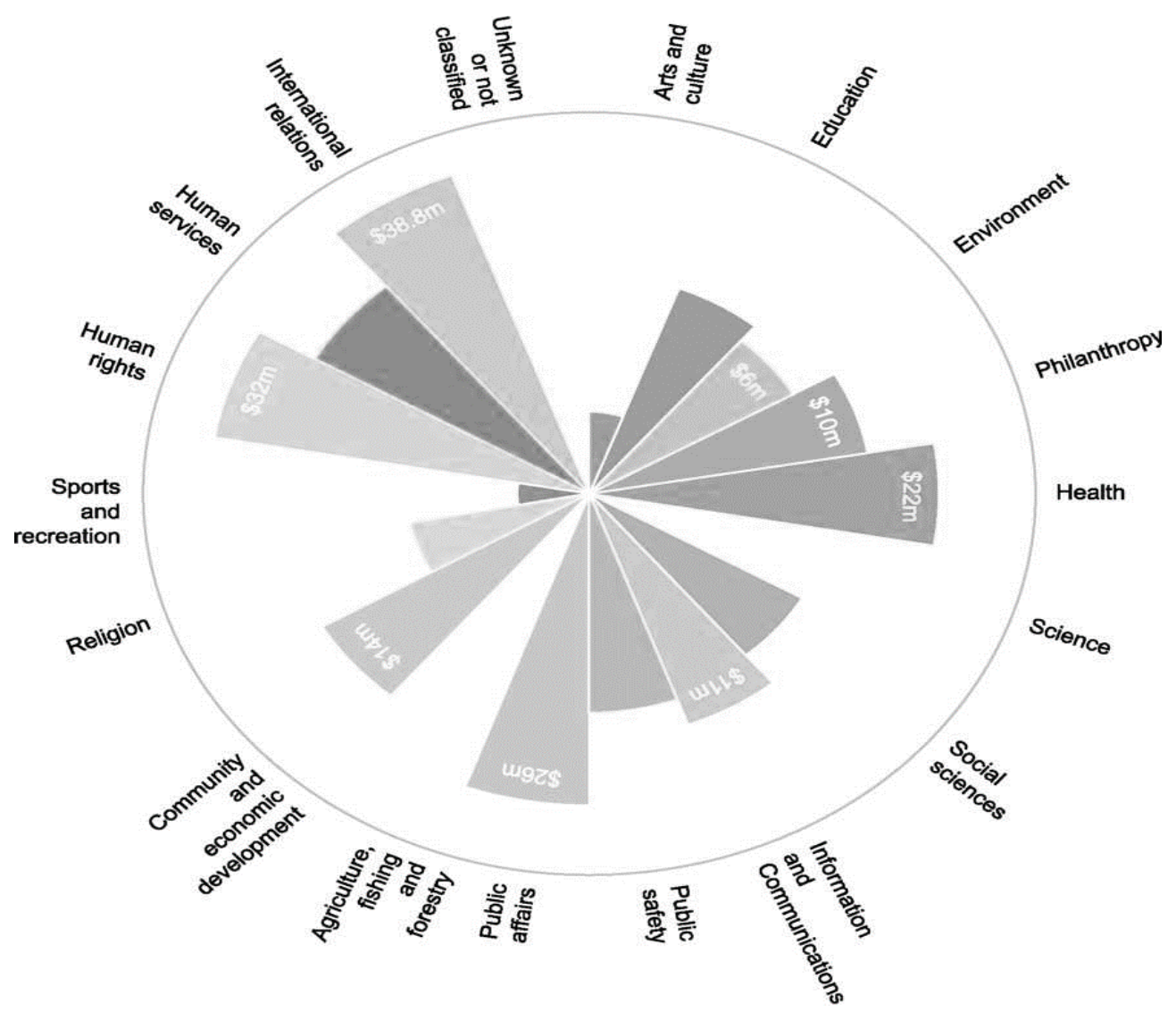

Figure 1. Main directions of grants in Ukraine for 2011-2018

Distribution of grants for goals is based on a certain algorithm. Each grant may belong to different target classifiers. Therefore, the total amount of distribution does not correspond to the total amount of grants. Significant amounts were allocated to medicine, the protection of human rights, and the development of civil society. Compiled based on Burakovsky I., Angel Ye., Kravchuk V., Yuhimenko S. (2018) 
From ancient to modern times, charitable activity is carried out in the forms of patronage, sponsorship, volunteering, fundraising. Modern trends of charity include: increase of the non-profit sector and its internationalization; cooperation of charitable foundations, development of a social partnership with business, state bodies, and foreign funds; professionalization through the creation of network charity. In turn, charity abroad is characterized by growing professionalism, a variety of forms and programs of cooperation, the growth and expansion of the sphere itself and its importance for non-profit, in particular, socio-cultural activities. The undisputed leader in this area is the USA - the birthplace of modern sponsorship and fundraising.

In recent years, the process of institutionalization of charity has intensified in Ukraine: the number of specialized funds is increasing; there appear public organizations whose tasks are to coordinate the efforts of various charitable actors.

On a global scale, the foreign activity of the US foundations is significant, and the expenditures exceed the official foreign aid budgets of many countries. However, their presence in Ukraine is relatively low.
The volume of support is negligible compared to official support amounts: according to the OECD, the number of grants actually received by Ukraine from other states and multilateral donors in 2011-2017 amounted to more than 5 billion USD while less than 0.1 billion USD came to Ukraine from US foundations. But this does not exclude the role of private donors in solving certain problems, in particular, in terms of supporting civil society, protecting the rights of vulnerable groups of the population, etc.

In order to improve charitable activities in Ukraine, many more steps must be taken in the sphere of harmonization of the current legislation, the development of state and private mechanisms of socioeconomic policy, tax legislation, social and spiritual support of the needy groups of the population, whose number in the country is increasing year by year. And charity should not become the main mechanism for maintaining the living standard of the population; it should become an auxiliary mechanism for the development of the socio-cultural potential of the population, preventive and health complexes, and the scientific and educational level.

\section{References:}

Benevolensky, V. B., Mersiyanova, I. V. (2010). Potential and development paths philanthropy. Kiev: Nauka.

Building Foundations for Political Parties (05.06.2010). Retrieved from: https://www.cipe.org/blog/2010/05/06/ building-foundations-for-political-parties/

Burakovsky, I., Angel, Ye., Kravchuk, V., Yuhimenko S. (2018). Inozemni Undeterred Fund. Retrieved from: http://www.ier.com.ua/files//publications/Special_research/Funds2018_ua.pdf

Charitable Russia (1901). History of state, public and private philanthropy in Russia / ed. P. I. Lykoshina. St. Petersburg: St. Petersburg Electrical Printing. Vol. 1.

Deryuzhinsky, V. F. (1897). Notes on public charity. Moscow: Publisher bookstore Grosman and Knebel.

Dakowska, Dorota (2017). German Political Foundations: Transnational party go-betweens in the process of EU enlargement. Retrieved from: https://halshs.archives-ouvertes.fr/halshs-00266910/document

Paweł Dziekański (2017). Economic effectiveness of the activities of local self-government units in the light of the municipality financial resources. Naukovyy visnyk Polissya, 3(11), 76-82.

Foundation Directory Online. Retrieved from: https://fconline.foundationcenter.org/ and https://maps.foundationcenter.org/home.php

Govorenkova, T. M. (2004). Charity and public charity, or that was in Russia before the Soviet "social security". Krasnodar: KubSU Publishing House.

Gulevskaya-Chernysh, A., Yaroshenko, L. (2016). Top Ukrainian philanthropists and troubled funds without reports and websites. Retrieved from: https://life.pravda.com.ua/society/2016/10/5/218672/view_print

Gulevskaya-Chershin, A. (2017). Charity in Ukraine: treason and victory in 2017. Retrieved from: https://life.pravda.com.ua/society/2017/12/26/228186/

IRS Data Book (2017). Retrieved from: https://www.irs.gov/pub/irs-soi/17databk.pdf

Kotilko, V. V. (2011). From charity to social security. Retrieved from: http://elib.org.ua/ruseconomics/ua readme.php

Law of Ukraine (2013). On Charitable Activities and Charitable Organizations. (Vidomosti Verkhovnoy Rady (VVR), 2013, № 25, Art. 252). Retrieved from: http://zakon2.rada.gov.ua/laws/show/5073-17

Levandovsky, A. P. (1995). Charlemagne: Through the empire to Europe. Moscow: Soratnik.

Lanchukovska, L. I. (1997). Traditions of charity in Odessa. Actual problems of politics: zbirnik naukovih prats. Odessa: Astroprint.

Martynyuk, O. A. (2015). Formation of the imperatives of sustainable development for structural transformations of the economy. Bulletin of Odessa National University. Series: Economics, 20(6), 44-48.

Menger, Carl (1870). Principles of Economics. James Dingwall and Bert F. Hoselitz. trans. Grove City. Penn.: Libertarian Press. 1994. 
Mises, Ludwig von (1949). Human Action: A Treatise on Economics. Scholar's Edition. Auburn, Ala.: Ludwig von Mises Institute. 1998.

Opilat, D. (2015). Thanks yak chinnik rozvitku podvilstvstva: vzagmodiya sotsiumu power. Humanitarian Newsletter of the Constipation of the State Academy of Engineering, 60, 160-166.

Organizations Balance USA (2015). Organizations: Balance Sheet and Income Statement Items, by Code Section, Tax Year (2015). Retrieved from: https://www.irs.gov/pub/irs-soi/15eo03.xlsx

Popov, D. (1907). Church charity among the clergy in the Kharkiv Diocese over the past decade. Kharkov: Publisher: Tipipografiya Gubernskogo government.

Private foundations (2010-2017). Retrieved from: http://www.u-.org.ua/privatni-fondi.htm

Rothbard, Murray N. (1998). The Ethics of Liberty. New York: University Press.

Raik, Kristi (2006). Promoting Democracy through Civil Society: How to Step up the EU's Policy towards the Eastern Neighbourhood. CEPS Working Document, No. 237/February 2006. Retrieved from: https://www.ceps.eu/ system/sles/book/1298.pdf

Shtal, I. V. (1978). Odyssey is a heroic poem of wandering. Moscow: Science.

Stupak, F. Ya. (2009). Charity and suspensions in Ukraine (18th century - the ear of XX century): [monograph]. Kiev: Institute of History of Ukraine NAS of Ukraine.

Tarasyuk, L. (2017). Key figures and facts about charity in Ukraine. Retrieved from: https://nachasi.com/ $2017 / 05 / 18 /$ charity/

The Social Progress (2013). The Social Progress Imperative: Ranking countries by level of social development in 2014. Retrieved from: http://gtmarket.ru/news/2014/04/14/6688

Toepler Stefan (2016). Foundations in Germany and the USA: Comparative Observations.

Vaillant, É. (1906). Social insurance [translation from French L. Borisovich]. Moscow: Labor and Will.

Vinnikov, Alexander (2008). Charitable and Private Foundations in Ukraine. Retrieved from: https://goo.gl/ Pu2xCf

World Giving Index (2013). Retrieved from: http://www.ukraine3000.org.ua/img/forall/mirovoi_reiting_ blagotvoritelnosti_2014

Yavornytskyi, D. (1991). Hetman Petro Konashevich-Sagaidachny. Dnipro: Sich. 